Political Networking Strategy and Firm Performance: A Moderated Mediation Model

Dr Yaqing Lin

School of Public Policy, Xiamen University, Xiamen, China

Dr Yan $\mathrm{Li}^{*}$

School of Management, Xiamen University, Xiamen, China

Email: liyangigi@xmu.edu.cn

Professor Shuming Zhao

School of Business, Nanjing University, Nanjing, China

Professor Steven J. Armstrong

Hull University Business School, The University of Hull, Hull, United Kingdom

Acknowledgements: This work was supported by the Ministry of education of Humanities and social sciences research foundation of China (Project No.15YJC630065) and the National Science Foundation of China (Project No. 71402153).

\footnotetext{
${ }^{*}$ Corresponding author and shared first authorship. Correspondence concerning this article should be addressed to Yan Li, School of Management, Xiamen University, China, Email: liyangigi@ xmu.edu.cn.
} 


\title{
Political Networking Strategy and Firm Performance: A Moderated Mediation
}

\section{Model}

\begin{abstract}
Purpose - By incorporating the resource-based view with the dynamic capability view, this study examines the link between corporate political networking strategy and firm performance in transition economies by focusing on the mediating role of corporate entrepreneurship and the moderating role of dysfunctional competition.
\end{abstract}

Design/methodology/approach - A large-scale questionnaire survey was conducted among 1,300 senior managers from 650 enterprises in China, and valid survey data were obtained from 401 enterprises.

Findings - Empirical results demonstrate that political networking strategy is positively related to firm performance, and that this relationship is fully mediated by corporate entrepreneurship. Moderated path analysis indicates that dysfunctional competition strengthens the direct effect of political networking strategy on corporate entrepreneurship and its indirect effect on firm performance via corporate entrepreneurship.

Originality/value - This research is among the first to examine the mediating mechanism underlying the relationship between political networking strategy and firm performance in the context of transition economies. In addition, existing research has seldom discussed the effects on corporate entrepreneurship of external resource acquisition from government sources. This research fills this important gap and identifies the condition under which political networking benefits corporate entrepreneurship. 
Keywords political networking strategy; corporate entrepreneurship; firm performance; dysfunctional competition; transition economy

Article type Research paper

\section{Introduction}

Understanding how to create and sustain corporate competitive advantage is the most fundamental concern of strategic management research (Hillman and Hitt, 1999). Previous studies have largely focused on the important role of market strategies in obtaining corporate competitive advantage under competition and cooperation, whereas the impact of political networking strategy and other corporate political activities has been ignored (Lawton et al., 2013; McGuire et al., 2014). Political networking strategy, as a typical form of corporate political activity, is a political means used by the corporate to strive for more beneficial policies and institutional support in the context of insufficient institutional infrastructure ( $\mathrm{Li}$ and Atuahene-Gima, 2001). More importantly, in comparison with Western market economies with relatively stable institutional environments, the role of political networking strategy is more vital in transition economy countries like China, which are experiencing significant institutional change as they move from central planning to market competition. Khanna and Rivkin (2001) highlighted the extreme importance of political networks in transition economies, where an open market for political favors does not exist. Because of the insufficient formal infrastructure and immature market mechanisms in transition economies, factor mobility is more constrained and the government controls a greater share of strategic factor resources. As such, political networking strategy and other corporate political activities have become the active response mechanism for firms to overcome institutional failure and are critical in providing firms with special access to various resources and legitimacy in transition economies (Lux et al., 2011; Zhang et al., 2015).

This is particularly the case when a unique aspect of China's culture that emphasizes the importance of managerial ties (guanxi in Chinese) is considered. In Chinese guanxi culture, a 
fundamental characteristic of Chinese interpersonal relationships is to identify different patterns of treatment according to different connections (Chen et al., 2004). Accordingly, the degree of proximity of the relationship between an enterprise and government officials will directly affect the government's support for the enterprise. The closer the relationship between the enterprise and government officials, the more resources such as information and funding the enterprise will obtain, which can contribute to its performance. It is thus critical for businesses in China to utilize political networks effectively in order to gain a competitive edge over competitors. However, although previous research has found evidence of a positive relationship between corporate political activity and firm performance in the context of developed economies (e.g. Hillman et al., 2004; Capron and Chatain, 2008), research concerning this issue has not received adequate empirical attention in the context of transition economies. Given that there are notable differences between developed economies and transition economies, existing findings regarding corporate political activities in developed economies cannot be generalized to transition economies, especially when exploring the influencing mechanisms in the different contexts. Therefore, this research will take political networking strategy as the point of breakthrough to explore whether firms' political relations with the government play a role in enhancing firm performance in the context of China's transition economy.

Second, how the resources obtained from firms' political networking strategies are employed to realize firm performance has not been studied closely in transition economies. One important characteristic of the institutional context of transition economies is the unceasing institutional transformation that accompanies the adjustment and upgrading of industrial structure under which firms gradually transform to become market-oriented operations (Peng and Luo, 2000). As a result of institutional transition and rapid economic growth, transition economies are characterized by volatile and fast-changing industry environments (Li et al., 2008; Yiu and Lau, 2008). According to the dynamic capability view, organizations need to continuously renew competences by configuring and transforming internal and external resources to address rapidly 
changing environments (Teece et al., 1997). As such, it is important for firms to undergo an entrepreneurial transformation at the organizational level in order to adapt to the transitioning institutional environment and sustain competitiveness in the market. Corporate entrepreneurship refers to firm-level behavioral phenomena characterized by innovation, venturing, and strategic renewal (Zahra and Dess, 2001). Research suggests that corporate entrepreneurship is the key for transition economy firms to revitalize resources and transform into market-oriented businesses that are ready to compete in the global economy (Hsu et al., 2014). Based on the dynamic capability view, this study proposes that during institutional transition, the positive effects of resources obtained from political networking strategy on firm performance are channeled through the resource configuration and transformation process given by particular corporate entrepreneurial activities such as product innovation and organizational structure transformation. Therefore, the second goal of this research is to build and test a model that explicitly outlines the mediating process underlying the relationship between political networking strategy and firm performance in a transition economy.

In addition, from the contingency theory perspective, the efficacy of enterprise strategy is context specific (Zahra and Garvis, 2000). However, few studies have examined the role that market forces play in the efficacy of political networking strategy in the transition economy context (Chen et al., 2014; McGuire et al., 2014). A transition economy represents an institutional context characterized by a lack of well-established legal frameworks to define property rights (Hoskisson et $a l .$, 2000). The lack of strong legal frameworks and institutional support has allowed widespread opportunistic behaviors and has affected the ability to enforce property rights. Dysfunctional competition refers to the extent to which the competition in a firm's business environment is perceived as opportunistic, unfair, or even unlawful (Li and Atuahene-Gima, 2001). Thus, one such important environmental characteristic in transition economies-dysfunctional competition-might exacerbate the efficacy of political networking strategy, thus affecting firms' activities and performance. Hence, the third purpose of this research is to examine the moderating role of 
dysfunctional competition on the relationships among political networking strategy, corporate entrepreneurship, and firm performance.

To address the gaps in the literature outlined above, this study examined the link between political networking strategy and firm performance by focusing on the mediating role of corporate entrepreneurship and the moderating role of dysfunctional competition, as illustrated in the conceptual model shown in Figure 1. In developing and testing this model, the present research advances the literature on political networking by elaborating how firms in transition economies configure and transform resources obtained from political networks for the realization of firm performance via corporate entrepreneurship. This study also extends previous research by providing evidence on how environmental characteristic influences the efficacy of enterprise strategy and thus identifies an important boundary condition under which political networking strategy is more or less beneficial.

Figure 1 about here

\section{Theoretical Foundations and Hypotheses}

\subsection{Political networking strategy and firm performance}

The resource-based view suggests that resources are an important source for enterprises to develop competitive advantage; and that enterprises can obtain resources through strategic factor markets (Barney, 1986; Adegbesan, 2009). However, in transition economies, there are still many imperfections in factor markets, meaning that resource mobility is severely constrained and enterprises find it difficult to directly access the resources necessary for development or must incur high costs to access the resources. As such, enterprises have to turn to political markets to establish political connections and thereby adopt an indirect method to acquire resources (Capron and Chatain, 2008; Rasche, 2015). In this context, policy demanders (such as enterprises) interact with policy providers (such as government officials) in political markets as a way of influencing policies in favor of the interests of those demanding them. In this interaction process, enterprises conduct a 
series of corporate political activities to build political networks and thus obtain beneficial resources to develop a competitive advantage and achieve better performance (Hillman et al., 2004).

Political networking strategy represents the extent to which a firm cultivate relationships with government officials, banks, and administrative and other regulatory agencies (Li and Atuahene-Gima, 2001; Hillman et al., 2004). In transition economies, government still controls a significant portion of strategic factor resources and has considerable power to allocate resources. Enterprises therefore tend to maintain "close relationships" with governments. Such managerial ties with government officials can substitute for insufficient institutional infrastructure and enable enterprises to obtain more resources, which can contribute to their performance (Xin and Pearce, 1996; Peng and Heath, 1996). Political networking strategy can effectively establish political relations with government, which counterbalances the negative influences that result from insufficient institutional infrastructure and guarantees the supply of resources necessary for an enterprise's development. By emphasizing political networking strategy, enterprises with extensive political networking can rely on such networks to obtain more beneficial resources and thereby improve firm performance. Therefore, the following is hypothesized:

- Hypothesis 1: Political networking strategy is positively related to firm performance in a transition economy.

\subsection{Political networking strategy and corporate entrepreneurship}

Early research on corporate entrepreneurship primarily considers corporate entrepreneurship as the activities of the individual entrepreneur. For example, Schumpeter (1950) contends that corporate entrepreneurship is a process of "creative destruction" in which the entrepreneur continually displaces or destroys existing products or methods of production with new ones. As the research proceeds, studies increasingly emphasize that corporate entrepreneurship is not confined to an entrepreneur's personal activities, but is a rather more extensive phenomenon at the organizational level. Specifically, corporate entrepreneurship is a firm-level behavioral phenomenon and all firms fall along a conceptual continuum that ranges from highly conservative to highly entrepreneurial. 
Entrepreneurial firms are risk-taking, innovative, and proactive (Barringer and Bluedorn, 1999; Zahra and Dess, 2001). Corporate entrepreneurship represents an internal organizational process that encompasses several types of phenomena and activities: innovation, venturing, and strategic renewal (Zahra and Dess, 2001).

Research has demonstrated that access to external resources can enhance corporate entrepreneurship (Teng, 2007). However, previous research has mostly treated external resources as those obtained from business partners, suppliers, and the personnel mobility of managers and engineers (e.g., Cassiman and Veugelers, 2006; Chen et al., 2014; Lee and Chu, 2013; Teng, 2007), neglecting external resource acquisition from government sources. This is because the primary research focus of corporate entrepreneurship has been on developed economies, where marketsupporting institutions are well developed, whereas in transition economies, institutional infrastructure is insufficient and the government continues to influence resource allocations, hence affecting firm activities (Sheng et al., 2011). In this research, we argue that political networking can be conducive to corporate entrepreneurship in transition economies for the following reasons.

First, in transition economies, as discussed earlier, political networking is critical in providing firms with special access to various resources and legitimacy. As such, governments may function as a resource allocation coordinator to facilitate corporate entrepreneurial activities. Political networking can support firms' innovations and ventures by negotiating favorable financing and tax policies, which helps firms avoid having to eliminate innovative ongoing projects and buffers them from downside risks in pursuing entrepreneurial activities. In addition, in transition economy countries such as China, enterprises have to seek government approval when they plan to engage in new ventures. Second, governments in transition economies guide their economic development by revising industry development plans and setting regulatory policies (Li and Zhang, 2007; Sheng et al., 2011). Political networking strategy enables firms to gain access to valuable industrial information and policies so that firms can integrate different elements of this knowledge to improve opportunity recognition and creative potential (Kotabe et al., 2016), which will then 
facilitate corporate entrepreneurial activities. For example, research suggests that high-quality industrial information facilitates new product development (Cassiman and Veugelers, 2006). Moreover, a timely understanding of regulatory policies helps firms in creating new ventures and renewing strategies (Sheng et al., 2011). Taken together, political networking strategy facilitates firms' innovation, venturing, and strategic renewal, which converge to form a higher level of corporate entrepreneurship. Accordingly, the following is hypothesized:

- Hypothesis 2: Political networking strategy is positively related to corporate entrepreneurship in a transition economy.

\subsection{Corporate entrepreneurship and firm performance}

With the development of the globalized economy, corporate entrepreneurship has become an effective way for enterprises to sustain competitiveness in the market (Morris et al., 2011). Corporate entrepreneurship has long been considered to be an important potential growth strategy for enterprises (Lin and Lee, 2011; Goodale et al., 2011). Research has highlighted that enterprises are increasingly dependent upon corporate entrepreneurship to develop sustainable competitive advantages (Ireland et al., 2006a, 2006b). Specifically, corporate entrepreneurship can help enterprises to create new internal combinatorial arrangements of resources, make full utilization of resources, and identify new opportunities for external growth, which all contribute to new product development, new market penetration, organizational structure transformation, and other approaches to improve firm performance (Lumpkin and Dess, 2001). Existing research has demonstrated that corporate entrepreneurship significantly promotes firm performance (e.g., Wright and Marlow, 2011; Lee and Chu, 2013), including empirical examinations in transition economies context (Luo et al., 2005; Ahlstrom and Ding, 2014). Accordingly, the following is hypothesized:

- Hypothesis 3: Corporate entrepreneurship is positively related to firm performance in a transition economy.

\subsection{The mediating role of corporate entrepreneurship}

In transition economies in which the formal institutional framework has not been well developed, 
there is coexistence between the market mechanism, which allocates resources mainly by market forces, and the redistributive mechanism by which allocations are mainly made by government (Zhou, 2000; Li and Zhang, 2007). Therefore, as a "nonmarket strategy" to obtain resources from the political environment, political networking strategy has become a focus of both academic and practical interest (Hillman et al., 2004; Capron and Chatain, 2008). Unfortunately, previous research on corporate political activity has focused mainly on the antecedents that generate these political activities, and whether the political activity gains competitive advantages for enterprises, while less attention has been paid to the mechanisms of influence underlying political networking strategy (Oliver and Holzinger, 2008; Lux et al., 2011). More importantly, due to continuous marketization in transition economies, it is necessary for firms to undergo an entrepreneurial transformation in order to adapt to the transitioning institutional environment (Chen et al., 2014; Hsu et al., 2014).

Based on the dynamic capability view, this study proposes corporate entrepreneurship as an organizational transformation mechanism that assists firms to adapt to changes during institutional transition. Specifically, corporate entrepreneurship performs a unique role in configuring and transforming the generic, nonmarket forms of resources obtained from political networking into industry-specific and firm-specific uses, thus continuously renewing firm competences and contributing to firm performance. Yiu and Lau (2008) provided empirical evidence for the mediating role of corporate entrepreneurial activities on the relationship between resource capital derived from informal networks and firms' relative performances. Following this, the present research proposes that the positive effects of political networking strategy on firm performance are channeled through the resource configuration and transformation process provided by corporate entrepreneurship. Political networking strategy, in itself, has some positive effects on firm performance. However, if the firms are highly conservative, then these effects may be limited in the transition economy context (Kotabe et al., 2016; Sheng et al., 2011). This is because the strategic value of those resources obtained from political networks cannot be realized without going through 
a transformation process that turns these resources into specific industry and firm uses. As such, corporate entrepreneurship serves as an intervening mechanism between political networking strategy and firm performance. Hence, the following is hypothesized:

- Hypothesis 4: Corporate entrepreneurship mediates the relationship between political networking strategy and firm performance in a transition economy.

\subsection{The moderating role of dysfunctional competition}

Dysfunctional competition refers to the extent to which the competition in a firm's business environment is perceived as opportunistic, unfair, or even unlawful (Li and Atuahene-Gima, 2001). Although dysfunctional competition can exist in any type of economy, it is more likely to occur in transition economies such as that of China. In a transition economy, formal market institutions have not been well developed to govern market transactions and protect property rights (Peng and Heath, 1996). Firms therefore engage in widespread opportunistic and unlawful behaviors in their business transactions (Li and Zhang, 2007), such as patent and copyright violations, broken contracts and agreements, and unfair competitive practices. Research has demonstrated that as an important environmental characteristic in transition economies, dysfunctional competition exerts a significant impact on a firm's business decisions and performance (Li and Atuahene-Gima, 2001; Li and Zhang, 2007). Because the efficacy of enterprise strategy is context specific (Zahra and Garvis, 2000), it is important to investigate whether political networking strategy benefits corporate entrepreneurship under different levels of dysfunctional competition.

This study argues that the positive relationship between political networking and corporate entrepreneurship is stronger when the level of dysfunctional competition in the industry is high compared with when it is low. When the market competition is highly dysfunctional, patents and copyright may go unprotected, and it may be difficult to monitor and enforce business contracts. Under such conditions, firms with extensive political networks could utilize favors to defend themselves against unfair competition (Dieleman and Sachs, 2008; Kotabe et al., 2016) and alleviate their resource constraints in conducting corporate entrepreneurial activities. Furthermore, 
political networking provides an alternative enforcement mechanism by gaining political legitimacy for firms (Sheng et al., 2011). Political networking could allow firms to persuade government agencies to enforce business contracts or even stop unlawful imitations by competitors. Hence, the positive effect of political networking strategy on corporate entrepreneurship is strengthened under high levels of dysfunctional competition. In contrast, when the environment is characterized by low levels of dysfunctional competition, the importance of political networking in both overcoming resource constraints and reducing risk will be reduced, thus lessening the impact of political networking strategy on corporate entrepreneurship. Therefore, the following is hypothesized:

- Hypothesis 5: Dysfunctional competition moderates the positive relationship between political networking strategy and corporate entrepreneurship in a transition economy such that the relationship is stronger when the level of dysfunctional competition is high rather than when it is low.

The above arguments represent an integrated framework in which corporate entrepreneurship mediates the impact of political networking on firm performance and dysfunctional competition moderates the relationship between political networking and corporate entrepreneurship. Thus, it is logical to predict that the positive indirect effect of political networking on firm performance via corporate entrepreneurship will be stronger when the level of dysfunctional competition is high. Hence, the following is hypothesized:

- Hypothesis 6: Dysfunctional competition moderates the indirect effect of political networking strategy on firm performance via corporate entrepreneurship in a transition economy such that the indirect effect is stronger when the level of dysfunctional competition is high rather than when it is low.

\section{Methodology}

\subsection{Sample and procedures}

Data for this research were collected from a questionnaire survey, which was completed with the 
assistance of alumni associations of our business schools and cooperating government departments. Questionnaires were distributed in the following two ways: One was to distribute and collect questionnaires on site. According to the list of firms provided by the alumni associations, these firms were contacted in advance and introduced to the research project. Then questionnaires were distributed on site along with instructions and guidance on the completion of the questionnaire. Each participant was instructed to place his or her completed survey in a sealed envelope and return it to researchers on the spot. Questionnaires were also distributed via cooperating government departments, with these departments in charge of the distribution. It should be noted that several measures were taken to minimize the potential effects of the government on data collection. For example, the government departments received sealed research packs and distributed them to participants. Each participant received a sealed research pack including a cover letter outlining the details of the study, the voluntary nature of participation, and an assurance of confidentiality; a questionnaire; and a return envelope. Participants were instructed to place their completed survey in a sealed envelope. The government departments then collected these sealed envelopes and sent them back to the researchers. Through these procedures, the survey instruments were distributed to 650 firms located in Beijing, Tianjin, Shanghai, Jiangsu, Zhejiang, Guangdong, and other areas of China.

To reduce the potential for common method bias, data were collected from two different sources. The respondents for the questionnaire survey were each firm's general manager and deputy general manager. In particular, general managers were asked to report on their firms' political networking strategy, corporate entrepreneurship, and firm performance, while deputy general managers were asked to evaluate the level of dysfunctional competition. All the respondents were asked to provide demographic information of their firms regarding size, ownership structure, and industry type. Data collection was conducted over nearly two years, and 1052 questionnaires were received from among the 1300 that were distributed to the firms. After eliminating questionnaires that were incomplete or could not be matched, the final sample consisted of 401 complete general 
manager-deputy general manager dyads, yielding an overall response rate of $62 \%$. Of the 401 firms that participated in this research, $20 \%$ were classified as state-owned $(N=82)$. The sample included firms from all types of ownership: state-owned enterprises, shareholding enterprises, private firms, joint ventures, etc. With respect to industry type, $31 \%$ of the sample firms were in high-technology industries. In terms of firm size, the number of employees in each firm ranged from 88 to 2200 . Firms that participated in this research constituted several different types of ownership, firm size, and industry, providing strong overall representation.

\subsection{Measures}

The survey was administrated in Chinese. Since the measures used in the study were originally developed in English, we followed the commonly used back-translation procedure to translate the measures into Chinese (Brislin, 1980). Moreover, following the recommendations of Schaffer and Riordan (2003), we consulted several managers in the surveyed firms to ensure that the items could be generalized to the research context. Respondents scored questions on 7-point Likert-type scales ranging from 1 (strongly disagree) to 7 (strongly agree) for all measures used in this research.

A four-item scale developed by Li and Atuahene-Gima (2001) was adapted to measure political networking strategy. The scale indicates the extent to which the firm over the past year has (1) spent much effort in cultivating personal connections with officials of government and its agencies, (2) maintained good relationships with officials of state banks and other governmental agencies, (3) devoted substantial resources to maintain good relationships with officials of administrative agencies, and (4) spent a lot of money on building relations with the top officials in government. The Cronbach's alpha for this scale was .85. A four-item scale developed by Li and Atuahene-Gima (2001) was used to measure dysfunctional competition. The scale indicates the extent to which the firm's principal industry has experienced the following in the last year: (1) unlawful competitive practices, (2) counterfeiting of the firm's own products and trademarks by 
other firms, (3) ineffective market competition laws to protect the firm's intellectual property, and (4) increased unfair competitive practices by other firms. The Cronbach's alpha for this scale was .75. Firm performance was measured by a seven-item scale developed by Wang et al. (2003) in the context of Chinese business environment. The respondents were asked to rate their own firm's performance as compared to the industry's average in the last year on (1) Profit, (2) Total sales, (3) Growth of sales, (4) Market share, (5) Employee morale, (6) Growth of assets, and (7) Competitive positioning. The Cronbach's alpha for this scale was .95.

A sixteen-item scale developed by Zahra (1996) was adapted to measure corporate entrepreneurship. We conducted a confirmatory factor analysis to test the three-dimensional structure of this measure. The fit indexes for three first-order factors plus one second-order factor fell within a good range: $\chi^{2} / 101=4.83$, RMSEA $=.10, \quad$ TLI $=.88, \quad$ CFI $=.91$. The Cronbach's alpha for this scale was .94 . Following previous studies, we aggregated the sixteen items to create a single index of corporate entrepreneurship (e.g., Zahra, 1996; Yiu and Lau, 2008).

We controlled for the following variables. First, firm size is controlled for, as it is found to have negative impacts on corporate entrepreneurship (Zahra, 1996). We measured firm size by the natural logarithm of the number of full-time employees. Second, we controlled for industry type because $31 \%$ of the sample firms were in high-technology industries. Firm industrial type was represented by a dummy variable, with a value of " 1 " indicates that the firm belongs to hightechnology industries and a value of " 0 " indicates otherwise. Third, we controlled for ownership structure in this research. Ownership structure was represented by a dummy variable, with a value of " 0 " indicates that the firm is state-owned enterprise and a value of " 1 " indicates otherwise. 


\section{Results}

\subsection{Assessment of research model}

Since the data on political networking strategy, corporate entrepreneurship, and firm performance were collected from the same source, we conducted a series of confirmatory factor analyses (CFAs) to evaluate the possibility of common method bias by testing whether these variables were distinct. In table 1, model 1 that included all three variables yielded an acceptable fit to the data. We further confirmed the discriminant validity of the three variables by contrasting model 1 against four alternative models (see table 1). For example, Model 2, in which political networking strategy and firm performance were combined into one factor and corporate entrepreneurship was distinct, and Model 5, in which all three factors were combined into one overall factor. Neither alternative model fits the data as well as model 1. In addition, all the factor loadings of the measures in this research were significant, demonstrating convergent validity.

Table 1 about here

Next, we further assessed the presence and influence of common method variance using the CFA marker technique (Williams et al., 2010). This method involves the inclusion of a latent marker, which is theoretically unrelated to any of the substantive variables in the study, to the CFA model. We opted for the variable technical uncertainty, measured with the four-item scale of Chen et al.'s (2005), because technical uncertainty has been shown to be mostly influenced by technological factors and less by firm factors (Rosenberg, 1998). In line with the recommendations of Williams et al. (2010), we first estimated a four-factor CFA model, consisting of the CFA model described above (including political networking strategy, corporate entrepreneurship, and firm performance) and the marker variable (technical uncertainty). Second, we tested a baseline model, in which the correlations between the latent marker variable and the other latent variables were fixed at zero, and 
the factor loadings and error terms of the marker variable indicators are fixed at the values obtained in the CFA model with marker variable. Third, we fitted a constrained model (Model-C) in which all indicators of the model loaded on the latent marker variable and all factor loadings were constrained to be equal. If this model has a better fit than the baseline model, common method variance is likely to be present and to have an equal effect on all indicators. This was not the case in our research (see Table 2). Fourth, we estimated an unconstrained model (Model-U) in which all indicators of the model loaded freely on the latent marker. If this model fits the data better than the constrained model, common method variance is likely to be present but to have an unequal effect on the different indicators. Table 2 shows that this is the case in our research. Finally, we tested a model in which the correlations between the substantive latent variables were constrained to the values obtained in the baseline model (Model-R). If this model has a significantly worse fit than the constrained or unconstrained model, common method variance is likely to bias the correlations between the latent variables. Table 2 shows that this was not the case in our research. We can thus conclude that although common method variance is present, it is unlikely to bias the relationships between our key variables (Williams et al., 2010).

Table 2 about here

Moreover, average variance extracted (AVE) was estimated for each scale and all of the AVEs were greater than .50 (AVE ranged from .54 to .72), thus further demonstrating convergent validity (Joreskog and Sorbom, 1993). Discriminant validity was tested through the Fornell and Larcker's (1981) approach, where the AVEs are compared to the shared variances. This procedure resulted in all AVEs being greater than the shared variances, indicating discriminant validity. Additionally, construct reliabilities were estimated and found to range from .78 (dysfunctional competition) to .95 (firm performance), which suggests that the scores generally were reliable 
(Bagozzi and Yi, 1988).

\subsection{Descriptive statistics}

Table 3 presents the means, standard deviations, and zero-order correlations of all variables. As shown in table 3, political networking strategy was positively correlated with corporate entrepreneurship $(r=.27, \mathrm{p}<.001)$ and firm performance $(r=.21, \mathrm{p}<.01)$. Moreover, corporate entrepreneurship and firm performance were positively correlated $(r=.64, \mathrm{p}<.001)$. The above results are consistent with and provide initial support for our hypotheses.

Table 3 about here

\subsection{Hypothesis Testing}

Hierarchical multiple regression analysis was conducted to test the first four hypotheses. The control variables, independent variable (political networking strategy), and mediator (corporate entrepreneurship) were entered in separate steps. Examination of the variance inflation factors associated with each regression coefficient showed a range of from 1.01 to 1.11 , suggesting no serious problems with multicollinearity (Cohen et al., 2003). As indicated in Table 4, political

networking strategy was positively related to firm performance $(\beta=.15, \mathrm{p}<.01$, Model 6), which explained 3 percent of the residual variance in firm performance. Thus, Hypothesis 1 was supported. The results also indicated that political networking strategy was positively related to corporate entrepreneurship $(\beta=.21, \mathrm{p}<.01$, Model 2$)$, which explained 6 percent of the residual variance in corporate entrepreneurship, and corporate entrepreneurship was positively related to firm performance $(\beta=.66, \mathrm{p}<.01$, Model 7$)$, which explained 38 percent of the residual variance in firm performance. Thus, Hypotheses 2 and 3 were supported.

Table 4 about here

Hypothesis 4 predicted that corporate entrepreneurship mediates the relationship between political networking strategy and firm performance. In support of Hypothesis 4, the results indicated that (1) political networking strategy was positively related to corporate entrepreneurship 
(hypothesis 2); (2) political networking strategy was positively related to firm performance (hypothesis 1); (3) corporate entrepreneurship was positively related to firm performance (hypothesis 3); and (4) after entering corporate entrepreneurship, the relationship between political networking strategy and firm performance became non-significant $(\beta=.02$, n.s., Model 8), while corporate entrepreneurship was still positively related to firm performance $(\beta=.65, p<.01$, Model 8). Thus, Hypothesis 4 received initial support. To further support Hypothesis 4, we used Zhao et al.'s (2010) approach, which uses a bootstrapping test to assess the significance of the direct and indirect paths within the model. The results indicated that the indirect effect of political networking strategy (through corporate entrepreneurship) on firm performance was significant $(\beta=.17, p$ $<.001)$. In addition, the direct effect of political networking strategy on firm performance was nonsignificant $(\beta=0)$. These results provide strong support for Hypothesis 4 and suggest that corporate entrepreneurship fully mediated the relationship between political networking strategy and firm performance.

Hypothesis 5 predicted that dysfunctional competition strengthens the positive relationship between political networking strategy and corporate entrepreneurship. To test this hypothesis, we adopted hierarchical multiple regression analysis. Both the independent variable and moderator were mean centered to minimize multicollinearity (Aiken and West, 1991). As shown in table 4, the interaction between political networking strategy and dysfunctional competition was positively related to corporate entrepreneurship $(\beta=.10, \mathrm{p}<.01$, Model 4$)$, which explained 2 percent of the residual variance in corporate entrepreneurship, thus supporting Hypothesis 5. To further interpret the interaction, we followed Aiken and West's (1991) approach by computing slopes using one standard deviation above and below the mean of the moderating variable. As shown in Figure 2, the relationship between political networking strategy and corporate entrepreneurship was not significant when the level of dysfunctional competition is low $(\beta=.11$, n.s.), but was positive when 
the level of dysfunctional competition is high $(\beta=.28, \mathrm{p}<.01)$. Thus, there is solid support for Hypothesis 5.

Figure 2 about here

Hypothesis 6 predicted that dysfunctional competition strengthens the indirect effects of political networking strategy on firm performance via corporate entrepreneurship. To test the moderated mediation effect, we conducted bootstrapping analyses. We used the SPSS applications provided by Edwards and Lambert (2007) and Preacher et al. (2007). Prior to moderated mediation analyses, the independent variable and moderator were mean centered to minimize multicollinearity (Aiken and West, 1991). As shown in table 5, the indirect effect of political networking strategy on firm performance via corporate entrepreneurship varied significantly across different levels of dysfunctional competition $(\Delta \beta=.06, \mathrm{p}<.01)$. Specifically, the indirect effect of political networking strategy on firm performance via corporate entrepreneurship was significant when dysfunctional competition was high $(\beta=.09, \mathrm{p}<.01)$, but was not significant when dysfunctional competition was low ( $\beta=.03$, n.s.). Hence, Hypothesis 6 was supported. Moreover, the results in Table 5 revealed significant first-stage moderating effects $(\Delta \beta=.10, \mathrm{p}<.01)$. Specifically, the effect of political networking strategy on corporate entrepreneurship was significant when dysfunctional competition was high $(\beta=.15, \mathrm{p}<.01)$ but was not significant when dysfunctional competition was low ( $\beta=.05$, n.s.), providing further support for Hypothesis 5. Finally, dysfunctional competition did not moderate the effect of corporate entrepreneurship on firm performance $(\Delta \beta=0$, n.s.), nor did it moderate the direct $(\Delta \beta=.02$, n.s. $)$ and total $(\Delta \beta=.08$, n.s. $)$ effects of political networking strategy on firm performance. Overall, the results of moderated path analysis provided support for first-stage moderation (Hypothesis 5) and moderated indirect effect via corporate entrepreneurship (Hypothesis 6). 
Table 5 about here

\section{Discussion}

Recently, researchers have increasingly emphasized the crucial roles of political networking strategy and other nonmarket strategies in enterprise survival and development, which represents an important research direction in strategic management. Despite the increase of studies on political networking strategy, little empirical research has considered this important issue in transition economies. By incorporating the resource-based view with the dynamic capability view, this research uses a multi-source research design to examine the impact of political networking strategy on firm performance in the context of China's transition economy. This study finds that political networking strategy positively affects firm performance. It also finds that corporate entrepreneurship mediates the effect of political networking strategy on firm performance, particularly under high levels of dysfunctional competition. By focusing on the moderating and mediating effects together, our model helps explain how political networking strategy affects firm performance and identifies the condition under which political networking strategy benefits corporate entrepreneurship. The theoretical and managerial implications and contributions of our findings are discussed below.

\subsection{Theoretical implications}

This research makes several important contributions to the literature. First, this study advances the literature on nonmarket strategy by examining the beneficial impact of political networking strategy on firm performance in the context of transition economies. Previous research on enterprise development has focused largely on enterprises' market strategies, while generally ignoring the roles of nonmarket strategies, such as political networking strategy (Hillman et al., 2004; Mellahi et $a l ., 2015)$. Our findings suggest that political networking strategy is critical in providing enterprises with special access to various resources and legitimacy in transition economies.

Second, this study advances the political networking strategy literature by examining the 
mediating mechanism underlying the relationship between this nonmarket strategy and firm performance. Drawing upon the dynamic capability view, we adopt a new theoretical framework to explain the mediating role that corporate entrepreneurship plays between political networking strategy and firm performance and indicate that an enhancement in corporate entrepreneurial activities could be an important path linking political networking and firm performance. Existing research has seldom discussed the effects on corporate entrepreneurship of external resource acquisition from government sources. Our results suggest that political networking helps firms gain access to diverse resources and compensates for deficiencies in the institutional environment, resulting in increased corporate entrepreneurship. These findings advance the current corporate entrepreneurship literature. Further, previous research has not addressed the path linking political networking strategy and firm performance. This study fills this important gap by providing the first empirical evidence of how political networking strategy affects firm performance via corporate entrepreneurship in the context of China's transition economy. Our study thus helps open the black box underlying the relationship between political networking and firm performance; it also adds to the literature of political networking strategy by including a dynamic capability perspective. Based on the dynamic capability view, this research has demonstrated the organizational transformation and resource configuration role played by corporate entrepreneurship that assists firms to adapt to changes during institutional transition. This suggests that political networking strategy can help firms to obtain various beneficial resources; however, a resource transformation and configuration mechanism is needed in order for these different types of resources to make contributions to firmspecific strategic outcomes. Hence, we highlight the relevance of taking a dynamic capability perspective in studying firms in transition economies.

More importantly, adopting the dynamic capability view, this research demonstrates how this new perspective complements most widely used theories in nonmarket strategy literature, such as resource dependence theory and resource-based view (Mellahi et al., 2015). Building on the resource-based view, this research affirms the importance of political networking strategy in 
transition economies by suggesting that political connections are critical in providing firms with resources and legitimacy in such institutional contexts. Further, following the dynamic capability view, this study emphasizes that corporate entrepreneurship performs a unique role in configuring and transforming the generic, nonmarket forms of resources obtained from political networking into industry-specific and firm-specific uses, thus continuously renewing firm competences and contributing to firm performance. By incorporating the resource-based view with the dynamic capability view, this research elaborates how resources obtained from the external environment are employed to add strategic value to firm performance. The results support the view that in transition economies, while firms have to rely on resources provided by political networking, they also need to undertake corporate entrepreneurial activities to transform these resources so as to renew their competences and adapt to continuous marketization in such institutional contexts.

Third, by adopting a contingency perspective, this study enriches the literature on political networking strategy by examining how dysfunctional competition could influence its efficacy. Although existing research has long recognized the benefits of political connections (e.g., Hillman et al., 2004; Li and Atuahene-Gima, 2001; Li and Zhang, 2007; Lux et al., 2011), research has yet to investigate the circumstances under which political networking strategy is effective. Our results suggest that under high levels of dysfunctional competition, firms with extensive political networking could utilize favors to reduce risk and overcome resource constraints, thus magnifying the positive impact of political networking strategy on corporate entrepreneurship and firm performance. By establishing the moderating influence of dysfunctional competition, this study extends prior research and identifies a new and important boundary condition under which political networking facilitates corporate entrepreneurial activities.

\subsection{Practical implications}

Our findings also have important practical implications. First, in transition economies, firms should be aware of the importance of political networking strategy and other nonmarket strategies in promoting firm performance. In the context of China's transition economy, this research 
demonstrates that political networking strategy can help firms to obtain the resources that are necessary for their survival and development. This suggests that in transition economies, firms not only need to obtain the required resources through market mechanisms, but also through the effective management of the political environment they face in order to improve firm performance. Second, our results suggest that in transition economies, political networking plays an important role in affecting firms' corporate entrepreneurial activities. Firms can exploit institutional support to their advantage when adapting their innovation and transformation plans to the dynamic business environment. In addition, the findings suggest that corporate entrepreneurship performs a unique role in configuring and transforming the resources obtained from political networks into firmspecific development. Hence, firms should pay attention to cultivating corporate entrepreneurship in the implementation of political networking strategy. Research has posited that political networking could become counterproductive (e.g., Fock and Woo, 1998; Warren et al., 2004); for example, a firm that opts for political networking strategy may rely too much on preferential treatment from the government to achieve business success, rather than pursue technological development on its own. Based on the resource configuration and transformation role of corporate entrepreneurship demonstrated in this research, we emphasize that the development of an entrepreneurial mindset and organizational transformation are particularly needed by firms in transition economies.

Third, our findings suggest that the extent to which firms can benefit from their political networking strategy depends upon the level of dysfunctional competition in their business environments. When the market competition is highly dysfunctional, firms can exploit institutional support to reduce risk and overcome their resource constraints in enhancing their corporate entrepreneurial activities. In summary, due to insufficient institutional infrastructure, governments still perform an important role in the process of resource allocation in transition economies. As such, firms should refine themselves "internally and externally" in their daily business activities. On the one hand, firms need to learn about their external market environment and implement appropriate political networking strategies to overcome the development dilemma resulting from institutional 
underdevelopment. On the other hand, firms should proactively conduct product and organizational innovations to transform the resources obtained from networks into difficult-to-replicate competences that are the source of their sustainable competitive advantage.

\subsection{Limitations and future research directions}

Despite these contributions, this research has several limitations. First, the cross-sectional data used in the research do not allow for causal interpretations among the variables. Second, this study's sample was limited to firms in China. Third, the data collection method in this research is based on survey only. Future research may explore alternative data collection methods such as archival data studies or case studies. Fourth, the present research only selected firm performance as the outcome of political networking strategy in firms in a transition economy context. Other potential firm-level outcomes may include return on asset, sales growth, and strategic flexibility (Nadkarni and Herrmann, 2010). Future research could also explore other strategic outcomes such as initial public offerings and private equity investments by reforming state-owned firms, as many of them are considering restructuring or privatizing portions of their assets. In addition, besides dysfunctional competition, future research could explore additional boundary conditions under which political networking strategy is more or less beneficial, such as institutional support and environmental uncertainty (Lawton et al., 2013). It would also be interesting to examine how the roles of political networking and corporate entrepreneurship differ between state-owned firms and non-state-owned firms.

\section{Conclusion}

By incorporating the resource-based view with the dynamic capability view, this research provides support for a theoretical model wherein enterprise political networking strategy enhances corporate entrepreneurship and ultimately contributes to firm performance in a transition economy context. Further, the moderating effect of dysfunctional competition helps us to identify a critical boundary condition for the aforementioned relationships. Hopefully, this study will encourage future research 
to advance our understanding of this important nonmarket strategy and assist firms to develop sustainable competitive advantages.

\section{References}

Adegbesan, J.A. (2009), "On the origins of competitive advantage: strategic factor markets and heterogeneous resource complementarity", Academy of Management Review, Vol. 34 No.3, pp. 463-475.

Ahlstrom, D. and Ding, Z. (2014), "Entrepreneurship in China: an overview”, International Small Business Journal, Vol. 32 No. 6, pp. 610-618.

Aiken, L.S. and West, S.G. (1991), Multiple Regression: Testing and Interpreting Interactions, Sage Publication, Thousand Oaks, CA.

Bagozzi, R.P. and Yi, Y. (1988), "On evaluation of structural equation models", Journal of Academy of Marketing Science, Vol. 16 No. 1, pp. 76-94.

Barney, J.B. (1986), "Strategic factor markets: expectations, luck, and business strategy", Management Science, Vol. 32 No. 10, pp. 1231-1241.

Barringer, B.R. and Bluedorn, A.C. (1999), “The relationship between corporate entrepreneurship and strategic management", Strategic Management Journal, Vol. 20 No. 5, pp. 421-444.

Brislin, R.W. (1980), Translation and Content Analysis of Oral and Written Materials. in Triandis, H.C., Berry, J.W. (Eds.), Handbook of Cross-cultural Psychology, Allyn and Bacon, Boston, pp. 389-444.

Capron, L. and Chatain, O. (2008), “Competitors' resource-oriented strategies: acting on competitors' resources through interventions in factor markets and political markets", Academy of Management Review, Vol. 33 No. 1, pp. 97-121. 
Cassiman, B. and Veugelers, R. (2006), "In search of complementarity in innovation strategy: internal R\&D and external knowledge acquisition", Management Science, Vol. 52 No. 1, pp. $68-82$.

Chen, C.C., Chen, Y.R. and Xin, K. (2004), "Guanxi practices and trust in management: a procedural justice perspective", Organization Science, Vol. 15 No. 2, pp. 200-209.

Chen, J.Y., Reilly, R.R. and Lynn, G.S. (2005), "The impacts of speed-to-market on new product success: the moderating effects of uncertainty", IEEE Transactions on Engineering Management, Vol. 52, pp. 199-212.

Chen, Y., Tang, G., Jin, J., Xie, Q. and Li, J. (2014), “CEOs' transformational leadership and product innovation performance: the roles of corporate entrepreneurship and technology orientation”, Journal of Product Innovation Management, Vol. 31 Supplement S1, pp. 2-17.

Cohen, J., Cohen, P., West, S.G. and Aiken, L. (2003), Applied Multiple Regression/Correlation Analysis for the Behavioral Sciences (3rd ed.), Mahwah, NJ: Lawrence Erlbaum.

Dieleman, M. and Sachs, W. (2008), "Economies of connectedness: concept and application", Journal of International Management, Vol. 14 No. 3. pp. 270-285.

Edwards, J. and Lambert, L. (2007), "Methods for integrating moderation and mediation: a general analytical framework using moderated path analysis", Psychological Methods, Vol. 12 No. 1, pp. 1-22.

Fock, H.K.Y. and Woo, K.S. (1998), "The China market: strategic implications of Guanxi”, Business Strategy Review, Vol. 9 No. 3, pp. 33-43.

Fornell, C. and Larcker, D.F. (1981), "Evaluating structural equation models with unobservable variables and measurement error", Journal of Marketing Research, Vol. 18, No. February, pp. $39-50$. 
Goodale, J.C., Kuratko, D.F., Hornsby, J.S. and Covin, J.G. (2011), “Operations management and corporate entrepreneurship: the moderating effect of operations control on the antecedents of corporate entrepreneurial activity in relation to innovation performance", Journal of Operations Management, Vol. 29 No. 2, pp. 116-127.

Hillman, A.J. and Hitt, M.A. (1999), “Corporate political strategy formulation: a model of approach, participation, and strategy decisions", Academy of Management Review, Vol. 24 No. 4, pp. $825-842$.

Hillman, A.J., Keim, G.D. and Schuler, D. (2004), “Corporate political activity: a review and research agenda", Journal of Management, Vol. 30 No. 6, pp. 837-857.

Hoskisson, R.E, Eden, L., Lau, C.M., and Wright, M. (2000), “Strategy in emerging economies", Academy of Management Journal, Vol. 43 No. 3, pp. 249-267.

Hsu, C.C., Tan, K.C., Jayaram, J. and Laosirihongthong, T. (2014), “Corporate entrepreneurship, operations core competency and innovation in emerging economies", International Journal of Production Research, Vol. 52 No. 18, pp. 5467-5483.

Ireland, R.D., Kuratko, D.F. and Morris, M.H. (2006a), "A health audit for corporate etrepreneurship: innovation at all levels-Part I", Journal of Business Strategy, Vol. 27 No. 1, pp. 10-17.

Ireland, R.D., Kuratko, D.F. and Morris, M.H. (2006b), "A health audit for corporate etrepreneurship: innovation at all levels-Part 2”, Journal of Business Strategy, Vol. 27 No. 2, pp. 21-30.

Joreskog, K. and Sorbom, D. (1993), LISREL8: Structural Equation Modeling with the SIMPLIS Command Language, Scientific Software, Chicago, IL. 
Khanna, T. and Rivkin, J.W. (2001), "Estimating the performance effects of business groups in emerging markets", Strategic Management Journal, Vol. 22 No. 1, pp. 45-74.

Kotabe, M., Jiang, C.X. and Murray J.Y. (2014), "Examining the complementary effect of political networking capability with absorptive capacity on the innovative performance of emergingmarket firms", Journal of Management, 0149206314548226.

Lawton, T., McGuire, S. and Rajwani, T. (2013), "Corporate political activity: a literature review and research agenda", International Journal of Management Reviews, Vol. 15 No. 1, pp. 86105.

Lee, T. and Chu, W. (2013), "How entrepreneurial orientation, environmental dynamism, and resource rareness influence firm performance”, Journal of Management \& Organization, Vol. 19 No. 2, pp. 167-187.

Li, J. J., Poppo, L. and Zhou, K. Z. (2008), "Do managerial ties in China always produce value? competition, uncertainty, and domestic vs. foreign firms", Strategic Management Journal, Vol. 29 No. 4, pp. 383-400.

Li, H.Y. and Atuahene-Gima, K. (2001), "Product innovation strategy and the performance of new technology ventures in China", Academy of Management Journal, Vol. 44 No. 6, pp. 11231134.

Li, H.Y. and Zhang, Y. (2007), "The role of managers' political networking and functional experience in new venture performance: evidence from China's transition economy", Strategic Management Journal, Vol. 28 No. 8, pp. 791-804.

Lin, S.J. and Lee, J.R. (2011), "Configuring a corporate venturing portfolio to create growth value: within portfolio diversity and strategic linkage", Journal of Business Venturing, Vol. 26 No. 4, pp. 489-503. 
Lumpkin, G.T., and Dess, G.G. (2001), "Linking two dimensions of entrepreneurial orientation to firm performance: the moderation role of environment and industry life cycle", Journal of Business Venturing, Vol. 16 No. 5, pp. 426-464.

Luo, X., Zhou, L. and Liu, S.S. (2005), "Entrepreneurial firms in the context of China's transition economy: an integrative framework and empirical examination”, Journal of Business Research, Vol. 58 No. 3, pp. 277-284.

Lux, S., Crook, T.R. and Woehr, D.J. (2011), "Mixing business with politics: a meta-analysis of the antecedents and outcomes of corporate political activity", Journal of Management, Vol. 37 No. 1, pp. 223-247.

McGuire, S., Lindeque, J. and Suder, G. (2014)," Learning and lobbying: emerging market firms and corporate political activity in Europe", European journal of international management, Vol. 6 No.3, pp. 342-362.

Mellahi, K., Frynas, J. G., Sun, P. and Siegel, D. (2015), “A review of the nonmarket strategy literature toward a multi-theoretical integration", Journal of Management, 0149206315617241.

Morris, M.H., Kuratko, D.F. and Covin, J.G. (2011), Corporate Entrepreneurship \& Innovation, Boston: Cengage/South-Western/Publishers.

Nadkarni, S. and Herrmann, P. (2010), “CEO personality, strategic flexibility, and firm performance: the case of the Indian business process outsourcing industry", Academy of Management Journal, Vol. 53 No. 5, pp. 1050-1073.

Oliver, C. and Holzinger, I. (2008), “The effectiveness of strategic political management: a dynamic capabilities framework", Academy of Management Review, Vol. 33 No. 2, pp. 496-520. 
Peng, M.W. and Heath, P. (1996), "The growth of the firm in planned economies in transition: institutions, organizations, and strategic choices", Academy of Management Review, Vol. 21 No. 2, pp. 492-528.

Peng, M. and Luo, Y.D. (2000), "Managerial ties and firm performance in a transition economy: the nature of a micro-macro link", Academy of Management Journal, Vol. 43, No. 3, pp. 486501.

Preacher, K.J., Rucker, D.D. and Hayes, A.F. (2007), “Addressing moderated mediation hypotheses: theory, methods and prescriptions," Multivariate Behavioral Research, Vol. 42 No. 1, pp. $185-227$.

Rasche, A. (2015), "The corporation as a political actor - European and North American perspectives”, European Management Journal, Vol. 33 No. 1, pp. 4-8.

Rosenberg, N. (1998), "Uncertainty and technological change - the economic impact of knowledge - chapter 1”, Economic Impact of Knowledge, Vol. 26 No. 5, pp.17-34.

Schaffer, B.S. and Riordan, C.M. (2003), "A review of cross cultural methodologies for organizational research: a best-practices approach", Organizational Research Methods, Vol. 6 No. 2, pp. 169-215.

Schumpeter, J.A. (1950), Capitalism, socialism, and democracy (3rd edn.), Harper and Row, New York.

Sheng, S., Zhou, K. and Li, J. J. (2011), "The effects of business and political ties on firm performance: evidence from China", Journal of Marketing, Vol. 75 No. 1, pp. 1-15.

Teece, D.J., Pisano, G. and Shuen, A. (1997), "Dynamic capabilities and strategic management", Strategic Management Journal, Vol. 18 No. 7, pp. 509-533. 
Teng, B.S. (2007), “Corporate entrepreneurship activities through strategic alliances: a resourcebased approach toward competitive advantage”, Journal of Management Studies, Vol. 44 No.1, pp. 119-142.

Wang, D.X., Tsui, A.S., Zhang, Y. and Ma, L. (2003), "Employment relationships and firm performance: evidence from an emerging economy", Journal of Organizational Behavior, Vol. 24 No. 5, pp. 511-535.

Warren, D., Dunfee, T. and Li, N. (2004), "Social exchange in China: the double-edged sword of Guanxi”, Journal of Business Ethics, Vol. 55 No. 4, pp. 355-372.

Wright, M. and Marlow, S. (2011), "Entrepreneurial activity in the venture creation and development Process”, International Small Business Journal, Vol. 30 No. 2, pp. 107-114.

Williams, L.J., Hartman, N., and Cavazotte, F. (2010), "Method variance and marker variables: a review and comprehensive CFA marker technique", Organizational Research Methods, Vol. 13 No.3, pp. 477-514.

Xin, K.R. and Pearce, J.L. (1996), "Guanxi: connections as substitutes for formal institutional support", Academy of Management Journal, Vol. 39 No. 6, pp. 1641-1658.

Yiu, D.W. and Lau, C.M. (2008), "Corporate entrepreneurship as resource capital configuration in emerging market firms", Entrepreneurship Theory and Practice, Vol. 32 No. 1, pp. 37-57.

Zahra, S.A. (1996), “Governance, ownership, and corporate entrepreneurship: the moderating impact of industry technological opportunities", Academy of Management Journal, Vol. 39 No. 6, pp. 1713-1735.

Zahra, S.A. and Dess, G. (2001), "Defining entrepreneurship as a scholarly field”, Academy of Management Review, Vol. 26 No. 1, pp. 8-10. 
Zahra, S.A., and Garvis, D.M. (2000), "International corporate entrepreneurship and firm performance: the moderating effect of international environmental hostility", Journal of Business Venturing, Vol. 15 No. 5-6, pp. 469-492.

Zhao, X., Lynch, J. G. and Chen, Q. (2010), "Reconsidering Baron and Kenny: myths and truths about mediation tests", Journal of Consumer Research, Vol. 37 No. 2, pp. 197-206.

Zhang, J., Tan, J. and Wong, P.K. (2015), "When does investment in political ties improve firm performance? the contingent effect of innovation activities", Asia Pacific Journal of Management, Vol. 32 No. 2, pp. 363-387.

Zhou, X. (2000), "Economic transformation and income inequality in urban China: evidence from panel data", American Journal of Sociology, Vol. 105 No. 4, pp. 1135-1174. 
Table 1 Results of confirmatory factor analysis

\begin{tabular}{lccccccc}
\hline Model & Factor & $\chi^{2}$ & $\mathrm{df}$ & $\chi^{2} / \mathrm{df}$ & RMSEA & TLI & CFI \\
\hline Model 1 & 3 factors: PNS;FP;CE & 287.70 & 87 & 3.31 & .08 & .93 & .95 \\
Model 2 & 2 factors: PNS+FP;CE & 965.75 & 89 & 10.85 & .16 & .70 & .78 \\
Model 3 & 2 factors: PNS+CE;FP & 955.06 & 89 & 10.73 & .16 & .70 & .78 \\
Model 4 & 2 factors: PNS;CE+FP & 803.39 & 89 & 9.03 & .14 & .75 & .82 \\
Model 5 & 1 factor: PNS+FP+CE & 1464.06 & 90 & 16.27 & .20 & .53 & .65 \\
\hline
\end{tabular}

Notes: $\mathrm{N}=401$; TLI $=$ Tucker-Lewis index; $\mathrm{CFI}=$ comparative fit index; RMSEA $=$ root mean square error of approximation; $\mathrm{PNS}=$ political networking strategy; $\mathrm{FP}=$ firm performance; $\mathrm{CE}=$ corporate entrepreneurship.

Table 2 Model comparisons for CFA model with marker variable

\begin{tabular}{lcccccc}
\hline & $\chi^{2}(\mathrm{df})$ & CFI & TLI & RMSEA & $\chi^{2}$ difference & Model comparison \\
\hline CFA with & $409.94(146)$ & .95 & .93 & .07 & & \\
marker variable & & & & & & \\
Baseline model & $463.72(156)$ & .94 & .92 & .07 & & \\
Model-C & $405.89(155)$ & .95 & .94 & .06 & $57.84(1)$ & Vs. Baseline model \\
Model-U & $376.45(141)$ & .95 & .94 & .07 & $29.40(14)^{* *}$ & Vs. Model-C \\
Model-R & $378.45(144)$ & .95 & .94 & .06 & $2.00(3)$ & Vs. Model-U \\
\hline
\end{tabular}

Notes: $\mathrm{N}=401 ;{ }^{* *} p<.01$; TLI $=$ Tucker-Lewis index; $\mathrm{CFI}=$ comparative fit index; RMSEA = root mean square error of approximation.

Table 3 Correlations, means, standard deviations of all variables in the study

\begin{tabular}{llllllllll}
\hline Variables & Mean & SD & 1 & 2 & 3 & 4 & 5 & 6 & 7 \\
\hline 1. Ownership type & .80 & .50 & & & & & & & \\
2. Industry type & .31 & .46 & .07 & & & & & & \\
3. Firm size & 2.54 & 1.27 & $-.13^{*}$ & .03 & & & & & \\
4. Political networking strategy & 3.76 & 1.08 & .09 & -.03 & $.14^{* *}$ & $(.85)$ & & & \\
5. Corporate entrepreneurship & 4.14 & .90 & $.18^{* * *}$ & .05 & .03 & $.27^{* * *}$ & $(.94)$ & & \\
6. Firm performance & 4.30 & .93 & $.14^{* * *}$ & $.10^{*}$ & $.14^{* *}$ & $.21^{* *}$ & $.64^{* * *}$ & $(.95)$ & \\
7. Dysfunctional competition & 3.54 & 1.15 & $.10^{*}$ & .01 & -.03 & $.19^{* * * *}$ & $.12^{*}$ & -.05 & $(.75)$ \\
\hline
\end{tabular}

Notes: $\mathrm{N}=401 ;{ }^{*} p<.05 ;{ }^{* *} p<.01 ;{ }^{* * *} p<.001$; Internal reliability coefficients appear in parentheses along the main diagonal.

Ownership type: " 0 " = state-owned enterprise; " 1 " = otherwise.

Industry type: " 0 " = otherwise; " $1 "=$ high-technology industry. 
Table 4 Results for hypotheses testing

\begin{tabular}{|c|c|c|c|c|c|c|c|c|}
\hline & \multicolumn{4}{|c|}{$\mathrm{CE}$} & \multicolumn{4}{|c|}{ FP } \\
\hline & M1 & M2 & M3 & M4 & M5 & M6 & M7 & M8 \\
\hline Intercept & $3.87^{* * * * *}$ & $3.18^{* * * *}$ & $3.06^{* * * *}$ & $3.01^{* * * *}$ & $3.81^{* * * * *}$ & $3.30^{* * * * *}$ & $1.27^{\text {*** }}$ & $1.22^{* * * *}$ \\
\hline $\begin{array}{l}\text { Control variable } \\
\text { Ownership type }\end{array}$ & $.33^{* * * *}$ & $.28^{* *}$ & $.27^{* *}$ & $.27^{* *}$ & $.29^{* *}$ & $.25^{* *}$ & .07 & .07 \\
\hline Industry type & .06 & .08 & .08 & .09 & .17 & .19 & .13 & .13 \\
\hline Firm size & .04 & .01 & .01 & .01 & $.12^{* *}$ & $.10^{* *}$ & $.09^{* * * *}$ & $.09^{* *}$ \\
\hline $\begin{array}{l}\text { Independent vari } \\
\text { PNS }\end{array}$ & & $.21^{* * *}$ & $.20^{* * *}$ & $.21^{* * *}$ & & $.15^{* * *}$ & & .02 \\
\hline $\begin{array}{l}\text { Mediator } \\
\mathrm{CE}\end{array}$ & & & & & & & $.66^{* * * *}$ & $.65^{* * * *}$ \\
\hline $\begin{array}{l}\text { Moderator } \\
\text { DC }\end{array}$ & & & .05 & .04 & & & & \\
\hline $\begin{array}{l}\text { Interaction } \\
\mathrm{PNS} \times \mathrm{DC}\end{array}$ & & & & $.10^{* *}$ & & & & \\
\hline $\mathrm{R}^{2}$ & .04 & .10 & .10 & .12 & .05 & .08 & .44 & .44 \\
\hline$\Delta \mathrm{R}^{2}$ & $.04^{* *}$ & $.06^{* * * *}$ & .01 & $.02^{* *}$ & .05 & $.03^{* * * *}$ & $.38^{* * * *}$ & $.35^{* * * *}$ \\
\hline $\mathrm{F}$ & $4.77^{* *}$ & $10.36^{* * *}$ & $8.57^{* * * *}$ & $8.39^{* * *}$ & $7.23^{* * *}$ & $8.89^{* * *}$ & $74.55^{* * * *}$ & $59.61^{* * *}$ \\
\hline
\end{tabular}

Notes: $\mathrm{N}=401 ;{ }^{*} p<.05,{ }^{* *} p<.01,{ }^{* * *} \mathrm{p}<.001 ;$ PNS = Political networking strategy; $\mathrm{CE}=$ Corporate entrepreneurship; FP= Firm performance; $\mathrm{DC}=$ Dysfunctional competition.

Table 5 Results of the moderated path analysis

\begin{tabular}{|c|c|c|c|c|c|}
\hline \multirow{4}{*}{ Moderator variable } & \multicolumn{5}{|c|}{ PNS $(\mathrm{X}) \rightarrow \mathrm{CE}(\mathrm{M}) \rightarrow \mathrm{FP}(\mathrm{Y})$} \\
\hline & \multicolumn{2}{|c|}{ Stage } & \multicolumn{3}{|l|}{ Effect } \\
\hline & First & Second & Direct effects & Indirect & Total effects \\
\hline & $P_{M X}$ & $P_{Y M}$ & $\left(P_{Y X}\right)$ & $\left(P_{Y M} P_{M X}\right)$ & $\begin{array}{c}\left(P_{Y X}+\right. \\
\left.P_{Y M} P_{M X}\right)\end{array}$ \\
\hline $\begin{array}{l}\text { Simple paths for low dysfunctional } \\
\text { competition }\end{array}$ & .05 & $.66^{* * *}$ & 16 & .03 & .19 \\
\hline $\begin{array}{l}\text { Simple paths for high dysfunctional } \\
\text { competition }\end{array}$ & $.15^{* * *}$ & $.66^{* * *}$ & .18 & $.09^{* * *}$ & $.27^{* * *}$ \\
\hline Differences & $.10^{* *}$ & 0 & .02 & $.06^{* *}$ & .08 \\
\hline
\end{tabular}

Notes: $\mathrm{N}=401 ;{ }^{*} p<.05 ;{ }^{* *} p<.01 ; \mathrm{PNS}=$ political networking strategy, $\mathrm{CE}=$ corporate entrepreneurship, $\mathrm{FP}=$ firm performance; $\mathrm{P}_{\mathrm{MX}}$ : path from political networking strategy to corporate entrepreneurship; $\mathrm{P}_{\mathrm{YM}}$ : path from corporate entrepreneurship to firm performance; $\mathrm{P}_{\mathrm{YX}}$ : path from political networking strategy to firm performance; Tests of differences for the indirect and total effect were based on bias-corrected confidence intervals derived from bootstrap estimates. 


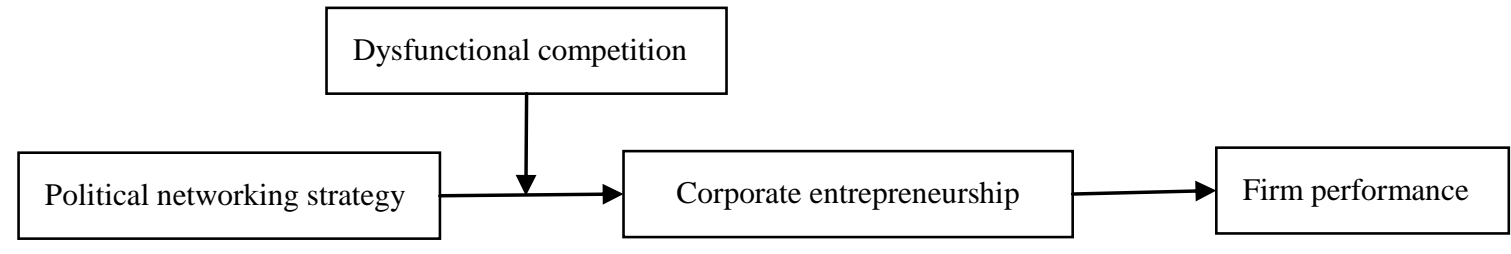

Figure 1. Theoretical model

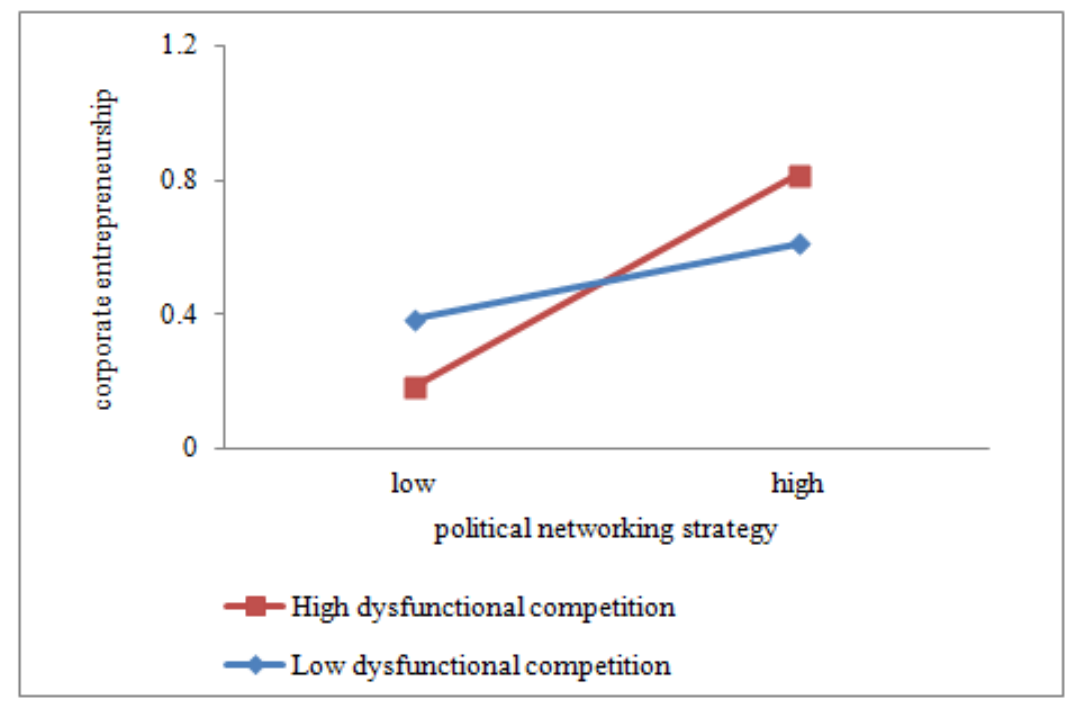

Figure 2. Interactive effects of political networking strategy and dysfunctional competition on corporate entrepreneurship 